\title{
KEEFEKTIFAN MODEL INVESTIGASI KELOMPOK DALAM PENINGKATAN KEMAMPUAN MAHASISWA TERHADAP APRESIASI CERITA PENDEK
}

\author{
Ruswendi Permana \\ Dosen Pendidikan Bahasa Indonesia \\ Universitas Pendidikan Indonesia \\ email: ruswendi@yahoo.com
}

\begin{abstract}
ABSTRAK
Penelitian ini dilandasi isu bahwa kemampuan apresiasi cerpen mahasiswa masih belum memuaskan. Oleh karena itu, perlu dicari faktor-faktor penyebab masalah tersebut serta upaya penanggulangannya. Salah satu upaya alternatif untuk menanggulangi masalah tersebut serta meningkatkan kemampuan mahasiswa dalam apresiasi cerpen adalah pembelajaran sastra melalui Model Investigasi Kelompok (MIK). Dalam penelitian ini digunakan metode eksperimen dengan desain kelompok kontrol prates-pascates yang dirandom. Data penelitian ini berupa hasil tes, hasil angket, hasil wawancara, dan hasil observasi. Hasil penelitian ini membuktikan bahwa MIK dapat menanggulangi kendala apresiasi cerpen serta efektif untuk meningkatkan kemampuan mahasiswa dalam apresiasi cerpen Indonesia. Dengan membandingkan hasil kemampuan awal dan akhir kelompok eksperimen dan kelompok kontrol serta kemampuan akhir kelompok eksperimen dan kelompok kontrol, dikonsultasikan dengan tabel Distribusi t, harga $\mathrm{t}_{1} \cdot \alpha$ pada $\alpha=0,01, \mathrm{n}=74$ ialah 2,37780, dan harga $\mathrm{t}_{\text {hitung }}$ sebesar 1,16943. Dengan demikian, $\mathrm{t}_{\text {hitung }}$ lebih kecil daripada harga $\mathrm{t}_{1} \cdot \alpha$, atau dengan kata lain kriteria $\mathrm{t}_{\text {hitung }}<\mathrm{t}_{1} . \alpha$ terpenuhi, atau Ha diterima. Jadi, hipotesis kemampuan apresiasi cerpen Indonesia mahasiswa yang menggunakan Model Investigasi Kelompok lebih tinggi daripada menggunakan Model Terlangsung diterima pada taraf nyata $\alpha=0,05$ atau tingkat kepercayaan $95 \%$. Dengan kata lain, MIK dalam pembelajaran apresiasi cerpen Indonesia secara kualitas efektif untuk meningkatkan kemampuan mahasiswa JPBD FPBS UPI. Penelitian ini menemukan bahwa prosedur yang digunakan dalam MIK, berkontribusi positif terhadap peningkatan kemampuan apresiasi cerpen Indonesia.
\end{abstract}

Kata kunci: model investigasi kelompok, apresiasi, cerpen, unsur intrinsik

\begin{abstract}
This study was based on the issue that the student's ability of short story appreciation was still satisfy. Therefore, it was needed to find out the factors causing the problem and solution to overcome in through the implementation of the investigation group model (IGM). It would provide lectures with alternatives for literature teaching that enable students to increase their ability in Indonesian short story appreciation. The study used the experimental methods with The Randomaized Pretest-Postest Comparison Group Design. The data were collected using questionnaire, interviews result, document, and observation result. The data collected were processed in quantitative and qualitative methods. Beside, the literature Indonesian lecture and some documents from the Sundanese Department saved as the additional source of the data. The result of this study proved that IGM could overcome the hindrance of literature appreciation, and it was also effective in increasing the students' competence of short story appreciation. The value of significance of two groups (Investigation Group Model and Exiting Model) short story competence was $\alpha=0.05$. In the validity level of $95 \%$, the value of significance was less than 0.05; therefore, the Ha was rejected. The result was also valid for significance value of the short story appreciation aspect's competence (theme and intension, plot, actor and character, setting, point of view and figurative langugae). Though they altogether increased the short story competence, it was seen that Investigation Group Model (IGM) was much better and more effective than the Conventional Model (CM) in student of Sundanese Department, Faculty of Language and Art, Indonesia University of Education. The study found that the procedur applied and developed in the GIM, that has never done before, contributed positively to the increase of short story appreciation competence.
\end{abstract}

Keywords: group investigation model, appreciation, intrinsic unit, short story

\section{PENDAHULUAN}

Berbicara tentang apresiasi sastra, termasuk apresiasi cerita pendek (cerpen), tidak terlepas dari pembicaraan tentang karya sastra itu sendiri. Tanpa adanya karya sastra, tentang apresiasi sastra tidak mungkin dibicarakan.
Apresiasi sastra dapat dilakukan dalam kegiatan formal, antara lain, di sekolahsekolah atau di kampus-kampus. Disinyalir bahwa kemampuan siswa atau mahasiswa dalam mengapresiasi karya sastra masih belum memuaskan. Artinya, kemampuan 
siswa atau mahasiswa dalam mengapresiasi karya sastra masih perlu ditingkatkan. Untuk meningkatkan kemampuan apresiasi sastra siswa atau mahasiswa, termasuk dalam apresiasi cerita pendek, dalam pembelajaran sastra dapat digunakan berbagai model pembelajaran. Salah satu model pembelajaran yang dapat digunakan untuk meningkatkan apresiasi sastra yang berupa cerita pendek adalah Model Investigasi Kelompok (MIK).

Ada beberapa alasan dilaksanakannya penelitian efektivitas Model Investigasi Kelompok dalam peningkatan apresiasi cerpen. Pertama, ada sinyalemen bahwa pembelajaran sastra di lembaga pendidikan formal masih kurang optimal, antara lain, tampak dariminat baca mahasiswa yang masih rendah. Bahkan dalam aspek pengetahuan sastra saja, mereka juga umumnya masih kurang dibandingkan dengan pengetahuan mereka tentang dunia selebriti. Munculnya masalah dalam bidang pendidikan ini merupakan gejala yang menunjukkan adanya kesenjangan antara hasil pendidikan dengan tuntutan kehidupan.

Kedua, keluhan-keluhan dalam pembelajaran apresiasi sastra di lembaga pendidikan formal berkisar pada minat belajar, minat baca, dan menulis sastra mahasiswa. Hal ini disebabkan (1) dalam proses pembelajaran, dosen masih menggunakan pola pembelajaran lama, misalnya masih memberikan materi sastra berkenaan dengan sejarah, namanama pengarang, dan bentuk-bentuk sastra saja; (2) dosen masih menggunakan model konvensional sehingga mahasiswa hanya sebagai objek bukan subjek; (3) mahasiswa hanya memahami makna literal, yakni hanya mengetahui teori sastra saja kurang dapat mengapresiasi sastra. Hal-hal inilah yang menyebabkan pembelajaran sastra selama ini kurang menarik dan tingkat apresiasi sastra mahasiswa rendah.

Ketiga, pembelajaran sastra seyogyanya membuat mahasiswa merasa nyaman, menyenangkan, dan menantang sehingga sastra dapat menjadi sarana pengembangan penalaran, kreativitas, kematangan pribadidan keterampilan sosial mahasiswa. Hal ini sesuai dengan tujuan pembelajaran apresiasi sastra, yakni agar mahasiswa mampu memahami, menikmati, dan memanfaatkan karya sastra guna mengembangkan kepribadian, wawasan kehidupan, meningkatkan pengetahuan, dan kemampuan berbahasa (Depdiknas, 2003).

Keempat, untuk mewujudkan idealisme pembelajaran sastra ini diperlukan reformasi pembelajaran sastra, baik secara teoretis-konseptual maupun secara teknis implementasinya seperti perumusan tujuan, metode, strategi, materi, media, dan evaluasi pembelajaran. Keseluruhan komponen teknis ini harus didesain sedemikian rupa sehingga pembelajaran sastra dapat menjadi sarana peningkatan daya nalar dan kreativitas mahasiswa. Hal ini perlu dilakukan agar pembelajaran sastra tidak monoton. Dalam pembelajaran yang konvensional atau terlaksana, mahasiswa ditempatkan sebagai objek belajar yang berperan sebagai penerima informasi secara pasif; mahasiswa lebih banyak belajar secara individual dengan menerima, mencatat, dan menghapal bahan ajar; pembelajaran bersifat teoretis dan abstrak, hanya berlangsung di dalam kelas; serta pengetahuan yang diperoleh mahasiswa bukan berdasarkan pengalaman, tetapi dikonstruksi oleh orang lain. Akibatnya hasil pendidikan hanya tampak dari kemampuan mahasiswa menghapal fakta-fakta. Meskipun banyak mahasiswa mampu menyajikan tingkat hafalan yang baik terhadap bahan ajar yang diterimanya, tetapi pada kenyataannya mereka seringkali tidak memahami secara mendalam substansi bahannya.

Berdasarkan kenyataan tersebut perlu dicari alternatif pemecahan masalahnya, baik nonformal di luar sekolah maupun formal di sekolah. Upaya nonformal di luar sekolah, antara lain, penerbitan berbagai buku karya sastra seperti yang dilakukan Surat Kabar 
Kompas secara periodik berupa kumpulan cerpen yang pernah dimuat di media tersebut dengan judul Cerpen Pilihan Kompas; Taufik Ismail beserta para sastrawan bekerja sama engan perguruan tinggi, sekolah, dan Kemendikbud secara periodik dan dalam lingkup nasional menyelenggarakan program SBMM (Satrawan Bicara Mahasiswa Membaca), SBSB (Sastrawan Bicara, Siswa Bertanya), dan MMAS (Membaca, Menulis, dan Apresiasi Sastra) bagi guru-guru bahasa dan sastra. Selain itu, pemerintah melalui Kemendikbud secara periodik melaksanakan program FLS2N (Festival Lomba Seni Siswa Nasional) yang seleksinya dimulai dari tingkat kecamatan. Di Perguruan Tinggi ada juga kegiatan Peksiminas (Pekan Seni Mahasiswa Nasional) yang dilaksanakan secara periodik.

Upaya formal di dalam sekolah dapat dilaksanakan melalui penerapan berbagai model pembelajaran yang dapat menarik dan membangkitkan minat para siswa atau mahasiswa. Penerapan beragam model ini untuk memperbaiki model pembelajaran terlaksana yang selama ini dilakukan oleh para dosen, antara lain, Model Investigasi Kelompok (MIK). Model ini dipilih karena memiliki tiga konsep dasar yang bersifat sentral, yakni pemeriksaan (inquiry), pengetahuan, dan dinamika kelompok (Joyce, Weil, \& Calhoun, 2009:319). Pembelajaran diawali dengan stimulus yang membuat mahasiswa dapat mereaksi dan menemukan konflik-konflik dasar antara sikap, gagasan, dan ragam persepsi mereka. Berdasarkan informasi ini, mahasiswa mengidentifikasi masalah yang harus dipecahkan, menganalisis peran-peran yang diperlukan untuk memecahkan masalah itu, mengatur diri mereka sendiri untuk mengambil peranperan itu, serta berbuat, melaporkan, dan mengevaluasi hasil-hasilnya. Langkahlangkah ini dilaksanakan dengan membaca, investigasi perseorangan, dan konsultasi dengan dosen pengampu.
Sampai saat ini, pembelajaran sastra Indonesia di Jurusan Pendidikan Bahasa Daerah FPBS UPI masih berorientasi kepada aspek kognitif sehingga kemampuan mahasiswa dalam memahami dan menganalisis sastra, termasuk cerpen, cenderung masih kurang optimal. Oleh karena itu, pembelajaran apresiasi cerpen melalui Model Investigasi Kelompok akan dicobaterapkan kepada mahasiswa peserta perkuliahan Sastra Indonesia.

Penelitian ini bertujuan menemukan dan memaparkan efektivitas atau keefektivan Model Investigasi Kelompok dalam meningkatkan kemampuan mahasiswa Jurusan Pendidikan Bahasa Daerah FPBS UPI Bandung dalam apresiasi cerpen Indonesia. Paparan atau deskripsinya mencakup empat hal, yakni (1) kondisi pembelajaran apresiasi sastra di Jurusan Pendidikan Bahasa Daerah FPBS UPI dengan Model Terlaksana, (2) kegiatan pembelajaran apresiasi cerpen Indonesia melalui Model Investigasi kelompok, (3) keefektivan Model Investigasi dalam meningkatkan kemampuan mahasiswa dalam apresiasi cerpen Indonesia, dan (4) keberterimaan dan kualitas Model Investigasi Kelompok dalam pembelajaran apresiasi cerpen Indonesia daripada Model Terlaksana.

\section{METODE PENELITIAN}

Metode eksperimen yang digunakan dalam penelitian ini termasuk eksperimen murni (true experiment) karena peneliti dapat mengontrol semua variabel luar yang mempengaruhi jalannya eksperimen. Validitas internal atau kualitas pelaksanaan rancangan penelitiannya menjadi tinggi. Ciri utama true experiment adalah sampel yang digunakan untuk kelompok eksperimen dan kelompok kontrol diambil secara random dari populasi tertentu. Untuk itu dipilih desain penelitian ini yang berupa desain kelompok kontrol prates-pascates yang dirandom (The randomized pretest-posttest control group design). Pada desain ini terdapat 
prates, perlakukan berbeda antara kelompok eksperimen dan kelompok kontrol, serta pascates (Fraenkel \& Wallen, 1993:248).

\section{$\begin{array}{llllll}\text { Treatment group } & \mathrm{R} & \mathrm{O} & \mathrm{X}_{1} & \mathrm{O}\end{array}$ \\ $\begin{array}{llllll}\text { Control group } & \mathbf{R} & \mathrm{O} & \mathrm{X}_{2} & \mathrm{O}\end{array}$}

Penggunaaan metode eksperimen dilakukan karena ingin mencari pengaruh perlakuan tertentu terhadap yang lain dalam kondisi yang terkendalikan (Sugiyono, 2008:72). Yang menjadi pengaruh perlakuannya adalah Model Investigasi Kelompok (MIK) dalam pembelajaran apresiasi cerpen, sedangkan yang dipengaruhinya adalah kemampuan mahasiswa dalam mengapresiasi cerpen Indonesia.

Untuk mengumpulkan data digunakan tiga teknik penelitian, yakni (1) teknik tes, (2) teknik angket, dan (3) teknik wawancara. Teknik tes digunakan untuk mengumpulkan data kemampuan apresiasi cerpen mahasiswa dengan menerapkan Model Investigasi Kelompok. Teknik angket digunakan untuk menjaring data yang berupa kesan, tanggapan, pendapat, dan penilaian mahasiswa mengenai kualitas Model Investigasi Kelompok dalam pembelajaran apresiasi cerpen Indonesia. Teknik wawancara digunakan untuk menjaring data yang berupa kesan atau tanggapan dosen mengenai pembelajaran apresiasi sastra Indonesia dan penerapan Model Investigasi Kelompok dalam apresiasi cerpen Indonesia.

Data yang akan dikumpulkan dalam penelitian ini meliputi data kualitatif dan data kuantitatif. Data kualitatif berkaitan dengan hasil analisis struktur penceritaan cerpen dan deskripsi hasil observasi berkaitan dengan penggunaan Model Invetigasi Kelompok (MIK) dalam pembelajaran apresiasi cerpen. Sementara, data kuantitatif berkaitan dengan hasil tes mahasiswa dalam pembelajaran apresiasi cerpen untuk melihat kemampuan mereka dalam mengapresiasi struktur penceritaan cerpen.

\section{HASIL DAN PEMBAHASAN}

\section{Hasil Penelitian}

Hasil penelitian ini menemukan perbandingan efektivitas antara model terlangsung (existing model) dengan model invetigasi kelompok (group investigation model). Untuk itu disajikan uji independen dalam regresi linier untuk kelompok eksperimen dan kelompok control.

Uji independen dalam regresi linier untuk kelompok eksperimen disajikan dalam daftar analisis variansi seperti tampak pada tabel 1 .

Tabel 1: Daftar Analisis Variansi untuk Uji Independen

Dalam Regrresi Linier Kelompok Eksperimen (A)

\begin{tabular}{lcrrrr}
\hline \multicolumn{1}{c}{ Umber Variasi } & Dk & \multicolumn{1}{c}{ JK } & \multicolumn{1}{c}{ RJK } & F & $\mathrm{F}_{\text {0end, }}$ \\
\hline Regresi a & 1 & $166.861,56$ & $166.861,56$ & & \\
\hline Regresi (bIa) & 1 & $1.968,16$ & $1.968,16$ & 54,91 & 7,37 \\
\hline Residu & 37 & $1.326,48$ & 35,85 & & \\
\hline J u m l a h & 37 & $170.156,50$ & & & \\
\hline
\end{tabular}

Berdasarkan tabel 1 tampak bahwa Fhitung adalah sebesar 54,91. Nilai $F_{\text {tabel }}$ dalam Distribusi $\mathrm{F}$ pada tingkat kepercayaan $\mathrm{p}=$ 99\% menunjukkan nilai 7,37. Nilai $\mathrm{F}_{\text {hitung }}$ lebih besar daripada nilai $\mathrm{F}_{\text {tabel }}$ yang artinya $\mathrm{H}: \theta 2=0$ ditolak; kemampuan akhir (hasil tes akhir) terhadap kemampuan awal (hasil tes awal) tidak independen dalam pengertian linier. Dengan demikian, pada kelompok eksperimen (A) kemampuan awal dapat digunakan untuk meramalkan kemampuan akhir. Dalam rumusan lain, garis regresi signifikan dapat dipakai sebagai alat peramal untuk nilai variabel terikat pada taraf nyata $\alpha$ $=0,01$, dengan persamaan regrsi $\mathrm{A}_{2}=21,72$ $+0,7453 \mathrm{~A}_{1}$.

Uji independen dalam regresi linier untuk kelompok kontrol disajikan dalam daftar 
analisis variansi seperti tampak pada tabel 2.

Tabel 2: Daftar Analisis Variansi untuk Uji Independen

Dalam Regrresi Linier Kelompok Kontrol (B)

\begin{tabular}{lcrrrr}
\hline \multicolumn{1}{c}{ Umber Variasi } & dk & \multicolumn{1}{c}{ JK } & RJK & F & $\mathrm{F}_{0,99(1,37)}$ \\
\hline Regresi a & 1 & $163.158,08$ & $163.158,08$ & & \\
\hline Regresi (bIa) & 1 & $1.526,13$ & $1.526,13$ & 41,32 & 7,42 \\
\hline Residu & 35 & $1.292,78$ & 36,94 & & \\
\hline J u m l a h & 37 & $170.156,50$ & & & \\
\hline
\end{tabular}

Berdasarkan tabel 2, tampak bahwa $\mathrm{F}_{\text {hitung }}$ adalah sebesar 41,32. Nilai $F_{\text {tabel }}$ dalam Ditribusi $\mathrm{F}$ pada tingkat kepercayaan $\mathrm{p}=$ 99\% menunjukkan nilai 7,42. Nilai $\mathrm{F}_{\text {hitung }}$ lebih besar daripada nilai $\mathrm{F}_{\text {tabel }}$ yang artinya $\mathrm{H}: \theta 2=0$ ditolak; kemampuan akhir (hasil tes akhir) terhadap kemampuan awal (hasil tes awal) tidak independen dalam pengertian linier. Dengan demikian, pada kelompok kontrol (B) kemampuan awal dapat digunakan untuk meramalkan kemampuan akhir. Dalam rumusan lain, garis regresi signifikan dapat dipakai sebagai alat peramal untuk nilai variabel terikat pada taraf nyata $\alpha$ $=0,05$, dengan persamaan garis regresi $\mathrm{B}_{2}=$ $20,44+0,7493 \mathrm{~B}_{1}$.

Berdasarkan perhitungan analisis regresi tersebut dapat disimpulkan bahwa pada kedua kelompok eksperimen dan kelompok kontrol, hubungan fungsional kemampuan awal (tes awal) dan kemampuan akhir (tes akhir) bersifat tidak independen, dengan persamaan regresi yang signifikan.

Selanjutnya, untuk membuktikan keefektifan model investigasi kelompok dibandingkan dengan model terlaksana, berikut ini disajikan uji hipotesis.

Hipotesis yang akan diuji dalam penelitian ini adalah "Pembelajaran Model Investigasi Kelompok lebih efektif daripada Model Konvensional dalam meningkatkan kemampuan mahasiswa JPBD FPBS UPI terhadapapresiasiceritapendek".Berdasarkan hasil uji perbedaan (dengan t-test), perbedaan dua rata-rata antara kemampuan awal dan akhir dapat menjawab hipotesis yang dirumuskan. Untuk mengujinya, berikut ini dikemukakan kembali hipotesis penelitian yang telah dirumuskan.

Ho: Pembelajaran dengan Model Invetigasi Kelompok tidak lebih efektif dalam meningkatkan kemampuan mahasiswa JPBD FPBS UPI terhadap apresiasi cerpen daripada Model Terlaksana (Exiting Model).

Ha : Pembelajaran dengan Model Invetigasi Kelompok lebih efektif dalam meningkatkan kemampuan mahasiswa JPBD FPBS UPI terhadap apresiasi cerpen daripada Model Terlaksana.

Untuk menguji hipotesis tersebut digunakan perbedaan dua rata-rata antara kemampuan awal (hasil tes awal) dan kemampuan akhir (hasil tes akhir) kelompok eksperimen (apresiasi cerpen Indonesia dengan Model Invsetigasi kelompok) dan kelompok kontrol (apresiasi cerpen Indonesia dengan Model Konvensional) pada taraf nyata $\alpha-0,05$ atau tingkat kepercayaan 95\%.

Analisis perbedaan dua rata-rata dilakukan terhadap rata-rata peningkatan atau gain (selisih tes awal dan tes akhir) kelompok eksperimen (A) dan kelompok kontrol (B). Dari hasil analisis tersebut diketahui bahwa rata-rata peningkatan kelompok eksperimen (dA) sebesar 6,78 serta peningkatan kelompok kontrol (dB) sebesar 5,07. Diketahui pula bahwa nilai $\mathrm{s}_{\mathrm{dA}}^{2}=40,96$ dan nilai $\mathrm{s}_{\mathrm{dB}}^{2}=40,66$, $\mathrm{n}_{1}=39$, dan $\mathrm{n}_{2}=37$.

Berdasarkan uji homogenitas telah diketahui bahwa peningkatan (gain) pada kedua kelompok itu homogen, dengan $\sigma^{2}{ }_{\mathrm{dA}}=\sigma_{\mathrm{dB}}^{2}=$ $\sigma$ tetapi $\sigma$ tidak diketahui, maka digunakan rumus statistik sebagai berikut. 
$\ddot{\mathrm{x}}_{1}-\ddot{\mathrm{x}}_{2}$

$\mathrm{t}=$ dengan

$\mathrm{s} 1 / \mathrm{n} 1+1 / \mathrm{n} 2$

$\left(\mathrm{n}_{1}-1\right) \mathrm{S}_{1}^{2}+\left(\mathrm{n}_{2}-1\right) \mathrm{S}_{2}^{2}$

$\mathrm{s} 2=\mathrm{n}_{1}+\mathrm{n}_{2}-2$
Dalam pengujian hipotesis digunakan kriteria pengujian untuk uji pihak kanan, yakni "Terima Ho, jika $\mathrm{t}<\mathrm{t}_{1}$. $\alpha$, dan tolak Ho jika mempunyai harga lain di mana $t_{2}$. $\alpha$ didapat dari daftar distribusi $\mathrm{t}$ dengan $\mathrm{dk}=\left(\mathrm{n}_{1}+\mathrm{n}_{2}\right.$ $-2)$. Hasil perhitungan dengan rumus-rumus di atas terlihat pada tabel 3 .

Tabel 3: Analisis Perbedaan Dua Rata-rata Peningkatan (Gain)

Kelompok Eksperimen $\left(\mathrm{d}_{\mathrm{A}}\right)$ dan Kelompok Kontrol $\left(\mathrm{d}_{\mathrm{B}}\right)$

\begin{tabular}{|c|c|c|c|c|c|c|}
\hline Gain $\left(\mathrm{d}_{\mathrm{i}}\right)$ & $\mathrm{d}_{\mathrm{i}}$ & $\mathrm{Ni}$ & $\mathrm{S}_{i}^{2}$ & $\mathrm{~S}^{2}$ & $t_{\text {hitung }}$ & $\mathrm{T}_{0,99,74}$ \\
\hline $\mathrm{d}_{\mathrm{A}}$ & 6,78 & 37 & 40,96 & 40,81 & 1,15943 & 2,37780 \\
\hline $\mathrm{d}_{\mathrm{B}}$ & 5,07 & 37 & 40,66 & 40,81 & 1,15945 & 2,31100 \\
\hline
\end{tabular}

Dikonsultasikan dengan tabel Distriusi t, harga $t_{1} . \alpha$ pada $\alpha=0,01, n=74$ ialah 2,37780, dan harga $t_{\text {hitung }}$ sebesar 1,16943. Dengan demimina, $t_{\text {hitung }}$ lebih kecil daripada harga $\mathrm{t}_{1} \cdot \alpha$, atau dengan kata lain kriteria $\mathrm{t}_{\text {hitung }}<\mathrm{t}_{1} \cdot \alpha$ terpenuhi, atau Ho diterima. Jadi, hipotesis kemampuan apresiasi cerpen Indonesia mahasiswa yang menggunakan Model Investigasi Kelompok lebih tinggi daripada menggunakan Model Terlaksana ditolak atau tidak diterima pada taraf nyata $\alpha=0,05$ atau tingkat kepercayaan 95\%.

Untuk mengetahui hasil yang lebih rinci, analisis perbedaan dua rata-rata akan dilakukan terhadap data hasil tes lainnya, yakni (1) tes awal dan tes akhir kelompok eksperimen (A), (2) tes awal dan akhir kelompok kontrol (B), (3) tes awal kelompok eksperimen (A) dan kelompok kontrol (B), dan (4) tes akhir kelompok eksperimen(A) dan kelompok kontrol(B). Dengan menggunakan rumus statistik uji-t serta perhitungan gain kelompok eksperimen dan kelompok kontrol didapat harga $s^{2}$ (gabungan) dan $t_{\text {hitung }}$ akan disajikan sebagai berikut.

\section{Kemampuan Awal (A1) dan Akhir (A2) Kelompok Eksperimen:}

Ho : A1 $\geq$ A2 Kemampuan awal lebih besar atau sama dengan Kemampuan akhir mahasiswa kelompok eksperimen

Ha : A1 < A2 Kemampuan awal lebih kecil daripada kemampuan akhir mahasiswa kelompok eksperimen.

Kriteria pengujian yang sesuai dengan hipotesis tersebut adalah kriteria pengujian untuk uji pihak kiri, yakni "Tolak Ho jika $\mathrm{t}_{\text {hitung }} \leq-\mathrm{t}_{1} \cdot \alpha$, di mana $\mathrm{t}_{1} \cdot \alpha$ didapat dari daftar distribusi t dengan $\mathrm{dk}=\left(\mathrm{n}_{1}+\mathrm{n}_{2}-2\right)$. Dengan menggunakan rumus statistik uji t, hasil perhitungan gain serta kriteria uji phak kir, diperoleh hasil seperti tampak pada tabel 4 .

Tabel 4: Analisis Perbedaan Dua Rata-rata

Kemampuan Awal $\left(\mathrm{A}_{1}\right)$ dan Kemampuan Akhir $\left(\mathrm{A}_{2}\right)$ Kelompok Eksperimen

\begin{tabular}{|c|c|c|c|c|c|c|}
\hline Nilai $\left(A_{i}\right)$ & $A_{i}$ & $\mathrm{Ni}$ & $\mathrm{S}_{i}{ }^{2}$ & $\mathrm{~S}^{2}$ & $\mathrm{t}_{\text {hituos }}$ & $\mathrm{T}_{0 c}$ \\
\hline Kemampuan Awal $\left(\mathrm{A}_{1}\right)$ & 61,80 & 37 & 93,26 & \multirow{2}{*}{89,98} & \multirow{2}{*}{$-3,15715$} & \multirow{2}{*}{2,37642} \\
\hline Kemampuan Akhir (A_) & 68,95 & 37 & 86,71 & & & \\
\hline
\end{tabular}

Berdasarkan tabel 4 di atas tampak bahwa pehitungan menghasilkan nilai tihitung sebesar -3,15715. Dikonsultasikan dengan tabel Distribusi t, harga $\mathrm{t}_{1}$. $\alpha$ pada $\alpha=0,01, \mathrm{n}=$ 76 ialah 2,37642, menunjukkan bahwa harga thitung sebesae minus 3,15715 lebih kecil daripada harga $-\mathrm{t}$. $\alpha$, atau memenuhi kriteria $\mathrm{t}_{\text {hitung }} \leq \mathrm{t}_{1} \cdot \alpha$, yang artinya bahwa Ho ditolak. Dengan demikian, dapat disimpulkan bahwa kemampuan akhir mahasiswa kelompok eksperimen (A2) lebih baik daripada kemampuan awalnya (A1) pada taraf nyata $\alpha$ $=0,05$ atau tingkat kepercayaan $95 \%$. 
Kemampuan Awal (B1) dan Akhir (B2) Kelompok Kontrol:

Ho : B1 $\geq$ B2 Kemampuan awal lebih besar atau sama dengan Kemampuan akhir mahasiswa kelompok kontrol.

Ha : B1 < B2 Kemampuan awal lebih kecil daripada kemampuan akhir mahasiswa kelompok kontrol.

Tabel 5: Analisis Perbedaan Dua Rata-rata Kemampuan Awal $\left(\mathrm{B}_{1}\right.$ ) dan Kemampuan Akhir $\left(\mathrm{BA}_{2}\right)$ Kelompok Kontrol

\begin{tabular}{|c|c|c|c|c|c|c|}
\hline Nilai $\left(B_{i}\right)$ & $\mathrm{B}_{i}$ & $\mathrm{Ni}$ & $\mathrm{S}_{i}^{2}$ & $\mathrm{~S}^{2}$ & $t_{\text {hitum }}$ & $\mathrm{T}_{0,9}$ \\
\hline Kemampuan Awal $\left(\mathrm{B}_{1}\right)$ & 61,34 & 37 & 75,50 & \multirow{2}{*}{76,90} & \multirow{2}{*}{$-2,48552$} & \multirow{2}{*}{2,379256} \\
\hline Kemampuan Akhir $\left(\mathrm{B}_{2}\right)$ & 66,41 & 37 & 78,30 & & & \\
\hline
\end{tabular}

Berdasarkan tabel di atas tampak bahwa pehitungan menghasilkan nilai tihitung sebesar -2,48552. Dikonsultasikan dengan tabel Distribusi t, nilai $\mathrm{t}_{1} . \alpha$ pada $\mathrm{t}_{(0,99.72)}$ ialah 2,379256, menunjukkan bahwa harga thitung sebesar minus 2,379256 lebih kecil daripada harga $-\mathrm{t} . \alpha,=2,379256$ atau dengan kata lain memenuhi kriteria $t_{\text {hitung }} \leq-t_{1}$. $\alpha$, yang artinya bahwa Ho ditolak. Dengan demikian, dapat disimpulkan bahwa rata-rata kemampuan akhir mahasiswa kelompok kontrol (B2) lebih baik daripada kemamuan awalnya (B1) pada taraf nyata $\alpha=0,05$.

\section{Kemampuan Awal Kelompok Eksperimen (A1) dan Kontrol (B1)}

Tabel 6: Analisis Perbedaan Dua Rata-rata

Kemampuan Awal Kelompok Eksperimen (A1) dan Kelompok Kontrol (B1)

\begin{tabular}{|c|c|c|c|c|c|c|}
\hline Nilai $\left(B_{i}\right)$ & $\mathrm{B}_{i}$ & $\mathrm{Ni}$ & $\mathrm{S}_{i}^{2}$ & $\mathrm{~S}^{2}$ & $t_{\text {hitung }}$ & $\mathrm{T}_{099674}$ \\
\hline Kemampuan Awal (A $)$ & 61,80 & 37 & 93,26 & \multirow{2}{*}{84,62} & \multirow{2}{*}{$-1,28351$} & \multirow{2}{*}{2,674392} \\
\hline Kemampuan Awal (B) & 61,34 & 37 & 75,50 & & & \\
\hline
\end{tabular}

Berdasarkan tabel 6 di atas tampak bahwa pehitungan menghasilkan nilai $t_{\text {hitung }}$ sebesar -1,26351. Dikonsultasikan dengan tabel Distribusi $\mathrm{t}$, harga $\mathrm{t}_{1} \cdot 1 / 2 \alpha$ pada $\mathrm{t}_{(0,996.74)}$ ialah 2,64392, menunjukkan bahwa harga $\mathrm{t}_{\text {hitung }}$ sebesar minus $-1,28351$ berada di antara harga $-\mathrm{t} 1.1 / 2 \alpha$, dan $\mathrm{t} 1.1 / 2 \alpha$ yang berarti tidak terdapat perbedaan yang signifikan antara kemampuan awal kelompok eksperimen (A1) dengan jemampuan awal kelompok kontrol (B1) pada taraf nyata $\alpha=0,05$.
Ho $:$ A1 $=$ B1 Kemampuan awal mahasiswa kelompok eksperimen sama dengan kemampuan awal mahasiswa kelompok kontrol.

Ha : $\mathrm{A} 1 \neq \mathrm{B} 1 \quad$ Kemampuan awal mahasiswa kelompok eksperimen tidak sama dengan kemampuan awal mahasiswa kelompok kontrol.

Kriteria pengujian yang sesuai dengan hipotesis tersebut adalah kriteria pengujian untuk uji pihak kiri, yakni "Tolak Ho jika $\mathrm{t} 1.1 / 2 \alpha<\mathrm{t}_{\text {hitung }}<\mathrm{t}_{1} \cdot 1 / 2 \alpha$, didapat dari daftar distribusi t dengan $\mathrm{dk}=\left(\mathrm{n}_{1}+\mathrm{n}_{2}-2\right)$. Hasilnya tampak pada tabel 6 .
Kriteria pengujian yang sesuai dengan hipotesis tersebut adalah kriteria pengujian untuk uji pihak kiri, yakni "Tolak Ho jika $\mathrm{t}_{\text {hitung }}<-\mathrm{t}_{1} \cdot \alpha$, di mana $\mathrm{t}_{1} \cdot \alpha$ didapat dari daftar menggunakan rumus statistik uji $t$, hasil perhitungan gain serta kriteria uji phak kir, diperoleh hasil seperti tampak pada tabel 5 . 
Kriteria pengujian yang sesuai dengan hipotesis tersebut adalah kriteria pengujian untuk uji pihak kiri, yakni "Tolak Ho jika $\mathrm{t} 1.1 / 2 \alpha<\mathrm{t}_{\text {hitung }}<\mathrm{t}_{1} .1 / 2 \alpha$, didapat dari daftar distribusi t dengan $\mathrm{dk}=\left(\mathrm{n}_{1}+\mathrm{n}_{2}-2\right)$. Dengan menggunakan rumus statistik uji t serta hasil perhitungan gain, didapat harga $\mathrm{s}_{2}$ (gabungan) dan $t_{\text {hitung }}$ seperti tampak pada tabel 7 .

Tabel 7: Analisis Perbedaan Dua Rata-rata

Kemampuan Akhir Kelompok Eksperimen (A2) dan Kelompok Kontrol (B2)

\begin{tabular}{|c|c|c|c|c|c|c|}
\hline Nilai & & $\mathrm{Ni}$ & $\mathrm{S}_{i}^{2}$ & $\mathrm{~S}^{2}$ & $\mathrm{t}_{\text {hitunc }}$ & $\mathrm{T}_{0.99674}$ \\
\hline Kemampuan Akhir $\left(\mathrm{A}_{2}\right)$ & 68,95 & 37 & 93,26 & \multirow{2}{*}{82,62} & \multirow{2}{*}{$-0,47706$} & \multirow{2}{*}{2,64392} \\
\hline Kemampuan Akhir (B, & 66,41 & 37 & 75,50 & & & \\
\hline
\end{tabular}

Berdasarkan tabel 7 di atas tampak bahwa perhitungan menghasilkan nilai $\mathrm{t}_{\text {hitung }}$ sebesar -0,47706. Dikonsultasikan dengan tabel Distribusi $t$, harga $t_{1} \cdot 1 / 2 \alpha$ pada $t_{(0,996.74)}$ ialah 2,6392, menunjukkan bahwa harga $t_{\text {hitung }}$ sebesar minus $-0,47706$ berada di antara harga $-\mathrm{t}_{1} .1 / 2 \alpha$, dan $\mathrm{t} 1.1 / 2 \alpha$ yang berarti tidak terdapat perbedaan yang signifikan antara kemampuan akhir kelompok eksperimen (A2) dengan kemampuan akhir kelompok kontrol (B2) pada taraf nyata $\alpha=0,01$. Meskipun demikian, peningkatan kemampuan akhir kelompok eksperimen (A2) lebih tinggi atau lebih signifikan daripada peningkatan kemampuan akhir kelompok kontrol (B2).

\section{Pembahasan}

Kegiatan pembelajaran apresiasi cerpen Indonesia melalui MIK dilaksanakan secara bertahap. Setiap tahap memiliki langkahlangkah tertentu sebagai gambaran skenario pembelajaran. Hal ini sejalan dengan teori yang diacu.

\section{Tahap Kegiatan MIK}

Pertama, tahap orientasi merupakan kegiatan awal, yakni pertemuan antara dosen dan mahasiswa. Tahap ini dilakukan untuk mengkondisikan mahasiswa serta mengobservasi gagasan yang dimilikinya sebelum pembelajaran. Dosen melakukan apersepsi yang berupa penjajagan kemampuan awal mahasiswa tentang cerita pendek, menghubungkan materi yang lalu dengan materi yang akan diajarkan, penyampaian tujuan pembelajaran. Untuk mengetahui kemampuan awal mahasiswa tentang cerpen, dosen memberikan soal tes awal kepada mahasiswa.

Kedua, tahap inkuiri merupakan tahap dosen mengatur kelas atau mengondisikan mahasiswa untuk belajar apresiasi cerpen dengan cara (1) membentuk kelompok mahasiswa dengan jumlah rata-rata 5-6 orang, (2) mengatur ruangan menjadi tempat berdiskusi untuk menemukan masalah tentang unsur intrinsik cerpen, dan (3) membagikan cerpen Indonesia dengan tema yang berbeda-beda kepada setiap kelompok untuk dianalisis unsur intrinsik cerpennya.

Ketiga, tahap pengetahuan merupakan tahap perolehan konsep yang diperoleh dari diskusi kelompok. Dalam diskusi kelompok ini, setiap kelompok mendiskusikan bahan yang berbeda-beda, yakni unsur intrnsik cerpen. Tiap kelompok mahasiswa mendiskusikan cerpen untuk merumuskan dan mencatat unsur intrinsik, yakni memahami (1) tema dan amanat, (2) alur, (3) tokoh dan watak, (4) latar, dan (5) sarana sastra (sudut pandang dan bahasa).

Keempat, tahap ini merupakan tahap mahasiswa melakukan diskusi kelompok untuk mengapresiasi unsur intrinsik cerpen Indonesia serta menyimpulkan hasilnya. Setiap wakil dari tiap kelompok tampil ke depan untuk menyajikan hasil diskusi kelompoknya.

Kelima, pada tahap ini dosen melakukan refleksi dan penyimpulan secara umum mengenai isi pembelajaran, termasuk pelaksanaan evaluasi pembelajaran dan tahap 
penutupan pembelajaran.

\section{Efektivitas MIK dalam Pembelajaran Apresiasi Cerpen Indonesia}

Efektivitas atau keefektifan MIK dalam pembelajaran apresiasi cerpen menunjukkan tingkat kualitasnya. Efektivitas MIK dalam pembelajaran apresiasi cerpen Indonesia di JPBD FPBS UPI didasarkan pada kriteria tertentu. Kriteria efektivitas ini telah terumuskan dalam hipotesis serta rinciannya dalam pertanyaan penelitian. Artinya, tingkat efektivitas MIK dapat diketahui melalui pengujian hipotesis.

Pertama, sistem sosial kelas MIK cukup terstruktur dan aktivitas pembelajaran berpusat pada mahasiswa. Aktivitas mahasiswa muncul dari struktur pembelajaran yang ditetapkan oleh dosen pada awal pembelajaran. Dosen berperan sebagai fasilitator atau mediator yang mengarahkan mahasiswa melaksanakan langkah-langkah yang harus ditempuh selama proses pembelajaran, baik kegiatan individu maupun kegiatan kelompok.

Kedua, prinsip-prinsip reaksi yang timbul selama pembelajaran apresiasi cerpen Indonesia dengan menggunakan MIK, antara lain, tampak sebagai berikut; (1) Mahasiswa melaksanakan langkah-langkah yang harus ditempuhdalamkegiataninvestigasikelompok dengan arah dosen sebagai fasilitator; (2) Mahasiswa didorong untuk bekerja sama dan berpikir kritis dalam mendiskusikan isi cerpen Indonesia; (3) Mahasiswa diberi kesempatan untuk bertanggung jawab menyelesaikan tugasnya, baik secara individual maupun secara berkelompok; (4) Aktivitas investigasi kelompok dalam bentuk diskusi kelompok berlangsung secara kooperatif dan demokratis, yakni mahasiswa dalam kelompoknya diberi kebebasan untuk curah gagasan dan perwakilan kelompok menyajikan hasil diskusi kelompoknya; dan (5) Proses pembelajaran dimarkahi dengan ciri responsif dan kolaboratif karena mahasiswa memberi tanggapan terhadap berlangsungnya proses pembelajaran dan bekerja sama salaing memberikan gagasan dalam mendiskusikan isi cerpen Indonesia yang diapresiasinya.

Ketiga, bahan utama dalam pembelajaran apresiasi cerpen Indonesia adalah cerpen Indonesia yang akan dianalisis unsur-unsur intrinsiknya. Banyak bahan cerpen yang dapat dipilih, baik yang sudah terkumpul dalam bentuk buku kumpulan cerpen maupun yang masih tersebar dalam majalah atau surat kabar. Cerpen Indonesia yang dipilih sebagai bahan ajar dan tes adalah tujuh cerpen Indonesia dan cerpen "Robohnya Surau Kami” karangan A.A. Navis. Cerpen lainnya sebagai bahan diskusi kelompok.

Keempat, penerapan tampak bahwa di dalam pelaksanaan pembelajaran apresiasi cerpen Indonesia dengan Model Investigasi Kelompok (MIK), dosen telah melaksanakan langkah-langkah kegiatan (syntax) yang disarankan. Mahasiswa aktif membaca cerpen, berdiskusi atau berkolaborasi untuk investigasi kelompok tentang unsurunsur intrinsik cerpen, dan menyajikan hasil diskusinya di depan kelas. Proses pembelajaran berlangsung dalam suasana yang kondusif, aktif, partisipasif, dan reaktif.

\section{KESIMPULAN}

Berdasarkan tujuan penelitian serta hasil pengolahan data yang dikemukakan pada bab terdahulu, terdapat beberapa simpulan berkaitan dengan penelitian ini.

a. Proses pembelajaran apresiasi cerpen dengan MIK

(1) Proses pembelajaran apresiasi cerpen Indonesia dengan Model Investigasi Kelompok (MIK) berlangsung dalam beberapa tahap, yakni (a) tahap orientasi, (b) tahap inkuiri, (c) tahap pengetahuan (diskusi kelompok), (d) tahap resitasi, dan (e) tahap 
perampatan.

(2) Cerpen Indonesia yang diajarkan adalah "Robohnya Surau Kami" karya A.A. Navis. Cerpen ini memiliki (a) tema moral, yakni kelalaian seorang kepala keluarga yang mengakibatkan dirinya terbunuh; amanatnya adalah keseimbangan hidup bahwa ketakwaan tidak hanya berdiam diri di masjid hanya menggantungkan belas kasihan orang, tetapi harus berusaha dan bekerja; (b) alur ceritanya adalah alur maju; (c) tokohnya adalah kakek yang tawakal menjaga sebuah surau dan Ajo Sidi seorang pembual; (d) latar yang menonjol adalah latar tempat, yani di sebuah kampung kecil yang terdapat sebuah surau; (e) sarana sastra, yakni sudut pandang yang digunakan adalah orang pertama dan orang ketiga; serta bahasa yang digunakan adalah ragam bahasa Indonesia sehari-hari.

(3) Aktivitas mahasiswa dalam pembelajaran apresiasi cerpen Indonesia dengan MIK berlangsung dengan baik. Hal itu dibuktikan dengan terlaksananya langkah-langkah kegiatan dengan MIK mencapai $89,47 \%$. Dengan terlaksananya hampir seluruh rangkaian kegiatan pembelajaran tersebut, dapat disimpulkan bahwa mahasiswa telah melakukan pembelajaran secara optimal.

(4) Hasil pembelajaran apresiasi cerpen Indonesia melalui Model Investigasi kelompok (MIK) menunjukkan adanya peningkatan. Hal ini terbukti dari kemampuan awal mahasiswa dalam apresiasi cerpen Indonesia tergolong cukup $(61,80)$, tetapi setelah mengikuti pembelajaran melalui Model Investigasi Kelompok (MIK) kemampuan akhirnya menjadi baik $(68,95)$. Artinya, terjadi peningkatan kemampuan mahasiswa dalam mengapresiasi cerita pendek Indonesia setelah pembelajaran dengan menggunakan Model Investigasi Kelompok (MIK). Hasil tersebut lebih tinggi apabila dibandingkan dengan kemampuan mahasiswa dalam apresiasi cerpen Indonesia kelompok kontrol tergolong cukup, baik sebelum $(61,34)$ maupun sesudah perlakuan Model Terlaksana (MT) (66,41). Memang ada peningkatan kemampuan mahasiswa, tetapi peningkatannya tidak signifikan.

b. Keefektifan Model Investigasi Kelompok Dalam pengujian hipotesis digunakan kriteria pengujian untuk uji pihak kanan, yakni "Terima Ho, jika $\mathrm{t}<\mathrm{t}_{1}$. $\alpha$, dan tolak Ho jika mempunyai harga lain di mana $t_{2}$. $\alpha$ didapat dari daftar distribusi $\mathrm{t}$ dengan $\mathrm{dk}$ $=\left(\mathrm{n}_{1}+\mathrm{n}_{2}-2\right)$. Dengan membandingkan hasil kemampuan awal dan akhir kelompok eksperimen dan kelompok kontrol serta kemampuan akhir kelompok eksperimen dan kelompok kontrol, dikonsultasikan dengan tabel Distribusi $\mathrm{t}$, harga $\mathrm{t}_{1} \cdot \alpha$ pada $\alpha=0,01, \mathrm{n}=74$ ialah 2,37780, da harga $t_{\text {hitung }}$ sebesar 1,16943. Dengan demikian, $\mathrm{t}_{\text {hitung }}$ lebih kecil daripada harga $\mathrm{t}_{1} \cdot \alpha$, atau dengan kata lain kriteria $\mathrm{t}_{\text {hitung }}$ $<\mathrm{t}_{1}$. $\alpha$ terpenuhi, atau Ho diterima. Jadi, hipotesis kemampuan apresiasi cerpen Indonesia mahasiswa yang menggunakan Model Investigasi Kelompok lebih tinggi daripada menggunakan Model Konvensional ditolak atau tidak diterima pada taraf nyata $\alpha=0,05$ atau tingkat kepercayaan 95\%. Dengan kata lain, MIK dalam pembelajaran apresiasi cerpen Indonesia secara kualitas efektif untuk meningkatkan kemampuan mahasiswa JPBD FPBS UPI.

c. Keberterimaan MIK oleh dosen dan mhasiswa diperoleh dari hasil observasi, angket, dan wawancara. Hasilnya menunjukkan bahwa MIK memberikan 
dampak positif karena (1) mengutamakan pembelajaran kolaboratif untuk mencapai tujuan bersama; (2) melibatkan semua anggota kelas dalam investigasi dan berdiskusi kelompok; (3) meningkatkan rasa tanggung jawab mahasiswa dalam belajar; (4) mengembangkan sikap toleransi dalam berhubungan dengan sesamanya; (5) meningkatkan keterampilan berbahasa (membaca, menulis, berbicara, dan menyimak); serta (6) meningkatkan berpikir kritis.

\section{DAFTAR PUSTAKA}

Depdiknas. 2003. Pedoman Kegiatan Belajar Mengajar Bahasa dan Sastra Indonesia. Jakarta:

Joyce, B. W., M \& Calhoun. 2002. Models of Teaching. Boston: Allyn and Bacon.

Joyce, B, Weil, M \& Calhoun. 2009. Model of Teaching. Diterjemahkan oleh Ahmad Fawaid \& Ateilla Mirza. Model-model Pengajaran. Yogyakarta: Pustaka Pelajar.

Sugiyono. 2008. Metode Penelitian Kuanttatif Kualitatirf dan R \& D. Bandung: Alfabeta.

Sugiyono. 2010. Statistika untuk Penelitian. Bandung: Alfabeta. 